\title{
Reactivity-Gated Photochromism of 1,2-Dithienylethenes for Potential Use in Dosiometry Applications
}

\author{
Vincent Lemieux and Neil R. Branda* \\ Department of Chemistry, Simon Fraser University, 8888 University Drive, Burnaby, BC, \\ Canada V5A 1 S6
}

\section{SUPPORTING INFORMATION}

\section{Experimental}

General: All solvents used for synthesis were dried and degassed by passing them through steel columns containing activated alumina under nitrogen using an MBraun solvent purification system. All other solvents were used as received. Solvents for NMR analysis were purchased from Cambridge Isotope Laboratories and used as received. Column chromatography was performed using silica gel 60 (230-400 mesh) from Silicycle Inc. All other reagents and starting materials were purchased from Aldrich. 1,2-Bis(2,5-dimethyl-3thienyl)ethanedione $\mathbf{5}^{1}$ and 1,4-butanebis(triphenylphosphonium) dibromide ${ }^{2}$ were prepared as described in the literature.

${ }^{1} \mathrm{H}$ NMR characterizations were performed on a Bruker AMX 400 instrument working at $400.103 \mathrm{MHz} .{ }^{13} \mathrm{C}$ NMR characterizations were performed on a Bruker AMX 400 instrument working at $100.610 \mathrm{MHz}$. Chemical shifts $(\delta)$ are reported in parts per million relative to tetramethylsilane using the residual solvent peak as a reference standard. Coupling constants $(J)$ are reported in Hertz. UV-VIS measurements were performed using a Varian Cary 300 Bio spectrophotometer.

\footnotetext{
${ }^{1}$ Ivanov, S. N.; Litchitskii, B. V.; Martynkin, A. Y.; Krayushkin, M. M. Chem. Heterocycl. Comp. 2001, 37, 85-90.

${ }^{2}$ Calcagno, P.; Kariuki, B. M.; Kitchin, S. J.; Robinson, J. M. A.; Philip, D.; Harris, K. D. M. Chem. Eur. J. 2000, 6, 2338-2349.
} 


\section{Syntheses}

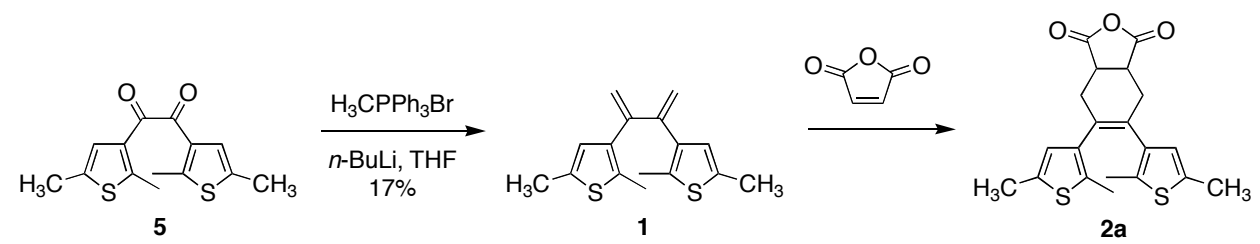

Synthesis of 2,3-bis(2,5-dimethyl-3-thienyl)-1,3-butadiene (1). $n$-Butyllithium (0.64 ml of a $2.5 \mathrm{M}$ solution in hexanes, $1.6 \mathrm{mmol})$ was added drop-wise to a cooled $\left(0{ }^{\circ} \mathrm{C}\right)$ suspension of methyltriphenylphosphonium bromide (568 mg, $1.6 \mathrm{mmol})$ in THF (50 mL). After the addition was completed, the ice bath was removed and the reaction mixture was allowed to slowly warm to room temperature, at which point it was stirred for 45 minutes. The resulting yellow solution was cooled to $-78{ }^{\circ} \mathrm{C}$ and treated drop-wise with a solution of diketone $5(89 \mathrm{mg}, 0.32 \mathrm{mmol})$ in THF $(10 \mathrm{~mL})$. The reaction mixture was stirred at $-78{ }^{\circ} \mathrm{C}$ for 30 minutes, the dry ice/acetone bath was removed and the reaction was allowed to warm to room temperature. After stirring overnight, the reaction was quenched by the addition of water $(50 \mathrm{~mL})$ and extracted with ether $(3 \times 50 \mathrm{~mL})$. The organic extracts were combined, washed with brine, dried over $\mathrm{MgSO}_{4}$ and filtered. The solvent was removed under reduced pressure and the residue was purified by column chromatography through silica (1:9 EtOAc:hexanes) to yield $15 \mathrm{mg}$ of diene $\mathbf{1}(17 \%)$ as a white solid.

$\mathrm{Mp}=43-44{ }^{\circ} \mathrm{C} ;{ }^{1} \mathrm{H} \mathrm{NMR}\left(\mathrm{CDCl}_{3}\right) \delta 6.52(\mathrm{~s}, 2 \mathrm{H}, \mathrm{CH}), 5.13\left(\mathrm{~d}, J=3.4 \mathrm{~Hz}, 2 \mathrm{H}, \mathrm{CH}_{2}\right), 5.09$ $\left(\mathrm{d}, J=3.4 \mathrm{~Hz}, 2 \mathrm{H}, \mathrm{CH}_{2}\right), 2.40\left(\mathrm{~s}, 6 \mathrm{H}, \mathrm{CH}_{3}\right), 2.31\left(\mathrm{~s}, 6 \mathrm{H}, \mathrm{CH}_{3}\right) \cdot{ }^{13} \mathrm{C} \mathrm{NMR}\left(\mathrm{CDCl}_{3}\right) \delta 144.5$, 137.7, 135.1, 133.0, 127.9, 118.5, 15.4, 14.1. MS (EI): $m / z=274\left(\mathrm{M}^{+}\right)$.

Synthesis of cyclohexene 2a: A solid mixture of 2,3-bis(2,5-dimethyl-3-thienyl)-1,3butadiene 1 (6.8 mg, $0.025 \mathrm{mmol})$ and maleic anhydride (4.9 mg, $0.05 \mathrm{mmol})$ was heated to $70{ }^{\circ} \mathrm{C}$ using an oil bath. Upon the complete melting of both solids, a pale pink solid formed. The cyclohexene product (2a) was purified by column chromatography through silica (1:4 EtOAc:hexanes) as a white solid.

${ }^{1} \mathrm{H} \mathrm{NMR}\left(\mathrm{CDCl}_{3}\right) \delta 6.32(\mathrm{~s}, 2 \mathrm{H}, \mathrm{CH}), 3.53(\mathrm{~d}, J=2.4 \mathrm{~Hz}, 2 \mathrm{H}, \mathrm{CH}), 2.96(\mathrm{~d}, J=15.1 \mathrm{~Hz}$, $\left.2 \mathrm{H}, \mathrm{CH}_{2}\right), 2.65\left(\mathrm{dd}, J=15.1,2.4 \mathrm{~Hz}, 2 \mathrm{H}, \mathrm{CH}_{2}\right), 2.33\left(\mathrm{~s}, 6 \mathrm{H}, \mathrm{CH}_{3}\right), 1.73\left(\mathrm{~s}, 6 \mathrm{H}, \mathrm{CH}_{3}\right)$. 


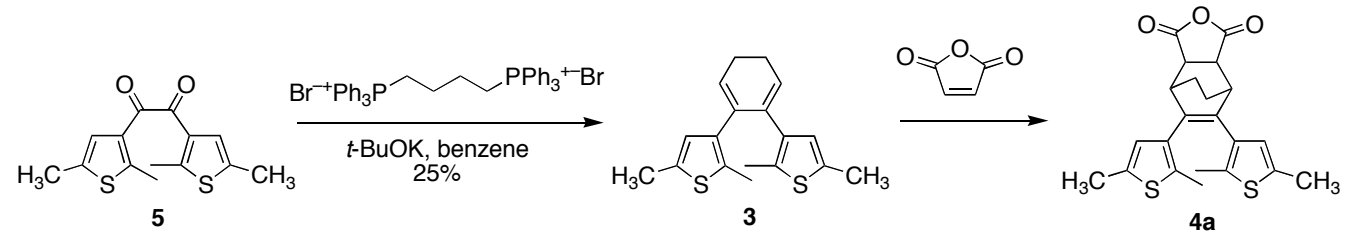

Synthesis of 3,4-bis(2,5-dimethyl-3-thienyl)cyclohexadiene (3). Potassium $t$-butoxide (163 mg, $1.45 \mathrm{mmol}$ ) was added to a suspension of 1,4-butanebis(triphenylphosphonium) dibromide $(537 \mathrm{mg}, 0.725 \mathrm{mmol})$ in benzene $(50 \mathrm{~mL})$. The reaction was stirred for $45 \mathrm{~min}$ at room temperature. The resulting orange solution was heated to reflux and treated dropwise with a solution of 1,2-bis(2,5-dimethyl-3-thienyl)ethanedione 5 (202 mg, $0.72 \mathrm{mmol}$ ) in benzene $(25 \mathrm{~mL})$. The reaction mixture was stirred at reflux for 20 minutes, at which point the heating mantle was removed and the reaction was allowed to cool to room temperature. The reaction was quenched by the addition of water $(50 \mathrm{~mL})$ and extracted with diethyl ether $(3 \times 50 \mathrm{~mL})$. The organic extracts were combined, washed with brine, dried over $\mathrm{MgSO}_{4}$ and filtered. The solvent was removed under reduced pressure and the residue was purified by column chromatography through silica (1:9 EtOAc:hexanes) to yield $55 \mathrm{mg}$ of cyclohexadiene $\mathbf{3}(25 \%)$ as a white solid.

$\mathrm{Mp}=55-57{ }^{\circ} \mathrm{C} .{ }^{1} \mathrm{H}$ NMR $\left(\mathrm{CDCl}_{3}\right) \delta 6.13(\mathrm{~s}, 2 \mathrm{H}, \mathrm{CH}), 5.88(\mathrm{~m}, 2 \mathrm{H},=\mathrm{CH}), 2.26(\mathrm{~m}, 10 \mathrm{H}$, $\left.\mathrm{CH}_{3}, \mathrm{CH}_{2}\right), 2.14\left(\mathrm{~s}, 6 \mathrm{H}, \mathrm{CH}_{3}\right) .{ }^{13} \mathrm{C} \mathrm{NMR}\left(\mathrm{CDCl}_{3}\right) \delta 137.8,134.4,133.9,131.6,127.4,126.7$, 22.7, 15.1, 14.0. MS (EI): $m / z=300\left(\mathrm{M}^{+}\right)$.

Synthesis of bicyclic product 4a. Procedure 1. 3,4-Bis(2,5-dimethyl-3thienyl)cyclohexadiene $3(5 \mathrm{mg})$ and maleic anhydride $(5 \mathrm{mg})$ were mixed in a $10 \mathrm{~mL}$ round bottom flask. The mixture turned from colorless to yellow within the first few seconds. After standing for $1 \mathrm{~h}$ at room temperature, product $\mathbf{4 a}$ was purified by column chromatography through silica (1:4 EtOAc:hexanes) as a white solid. The efficiency of the reaction was greatly improved when melting both components by heating to $70{ }^{\circ} \mathrm{C}$ in an oil bath.

${ }^{1} \mathrm{H} \mathrm{NMR}\left(\mathrm{CDCl}_{3}\right) \delta 6.45(\mathrm{~s}, 2 \mathrm{H}, \mathrm{CH}), 3.43(\mathrm{~m}, 2 \mathrm{H}, \mathrm{CHC}=\mathrm{O}), 3.26(\mathrm{~m}, 2 \mathrm{H}, \mathrm{CH}), 2.35(\mathrm{~s}$, 6H, $\left.\mathrm{CH}_{3}\right), 1.65\left(\mathrm{~s}, 6 \mathrm{H}, \mathrm{CH}_{3}\right), 1.54\left(\mathrm{~m}, 4 \mathrm{H}, \mathrm{CH}_{2}\right) . \mathrm{MS}(\mathrm{EI}): m / z=398\left(\mathrm{M}^{+}\right)$. 
Procedure 2. 3,4-Bis(2,5-dimethyl-3-thienyl)cyclohexadiene 3 (1 $\mathrm{mg})$ and maleic anhydride $(1 \mathrm{mg})$ were dissolved in acetone- $\mathrm{d}_{6}(1 \mathrm{~mL})$ in an NMR tube and heated at $65{ }^{\circ} \mathrm{C}$ in a water bath. The reaction went to completion after 7 days and no side products were observed by ${ }^{1} \mathrm{H}$ NMR spectroscopy.

${ }^{1} \mathrm{H}$ NMR (acetone- $\left.\mathrm{d}_{6}\right) \delta 6.55$ (s, 2H, CH), 3.54 (m, 2H, CHC=O), 3.35 (m, 2H, CH), 2.35 (s, 6H, $\left.\mathrm{CH}_{3}\right), 1.89\left(\mathrm{dm}, \mathrm{J}=7.4 \mathrm{~Hz}, 2 \mathrm{H}, \mathrm{CH}_{2}\right), 1.65\left(\mathrm{dm}, \mathrm{J}=7.4 \mathrm{~Hz}, 2 \mathrm{H}, \mathrm{CH}_{2}\right), 1.65(\mathrm{~s}, 6 \mathrm{H}$, $\left.\mathrm{CH}_{3}\right)$.

Procedure 3. 3,4-Bis(2,5-dimethyl-3-thienyl)cyclohexadiene $3\left(20.0 \mathrm{mg}, 6.8 \times 10^{-5} \mathrm{~mol}\right)$ and maleic anhydride $\left(6.5 \mathrm{mg}, 6.8 \times 10^{-5} \mathrm{~mol}\right)$ were dissolved in acetone- $\mathrm{d}_{6}(0.75 \mathrm{~mL})$ in an NMR tube and heated at $65{ }^{\circ} \mathrm{C}$ in a water bath. The reaction went to completion after 5 days and no side products were observed by ${ }^{1} \mathrm{H}$ NMR spectroscopy. Thin layer chromatography and ${ }^{13} \mathrm{C}$ NMR spectroscopy showed the presence of trace amount of impurities. The product was purified by column chromatography through silica (1:4 EtOAc:hexanes).

$\mathrm{Mp}=>185{ }^{\circ} \mathrm{C}$ (decomposition). ${ }^{1} \mathrm{H}$ NMR (acetone- $\left.\mathrm{d}_{6}\right) \delta 6.55(\mathrm{~s}, 2 \mathrm{H}, \mathrm{CH}), 3.54(\mathrm{~m}, 2 \mathrm{H}$, $\mathrm{CHC}=\mathrm{O}), 3.35(\mathrm{~m}, 2 \mathrm{H}, \mathrm{CH}), 2.35\left(\mathrm{~s}, 6 \mathrm{H}, \mathrm{CH}_{3}\right), 1.89\left(\mathrm{dm}, \mathrm{J}=7.4 \mathrm{~Hz}, 2 \mathrm{H}, \mathrm{CH}_{2}\right), 1.65(\mathrm{~m}$, $\left.2 \mathrm{H}, \mathrm{CH}_{2}\right), 1.65\left(\mathrm{~s}, 6 \mathrm{H}, \mathrm{CH}_{3}\right) .{ }^{13} \mathrm{C} \mathrm{NMR}\left(\right.$ acetone-d $\left._{6}\right) \delta 175.2,137.8,137.3,136.9,133.9$, 127.2, 46.8, 40.7, 25.2, 15.9, 14.8. $\mathrm{MS}(\mathrm{EI}): \mathrm{m} / z=398\left(\mathrm{M}^{+}\right)$.

Photochemistry. Standard lamps used for visualizing TLC plates (Spectroline E-series, $470 \mu \mathrm{W} / \mathrm{cm}^{2}$ ) were used to carry out the ring-closing reactions of all photochromic compounds in this study. The composition of the photostationary state of compound $4 \mathbf{a}$ was analyzed using ${ }^{1} \mathrm{H}$ NMR spectroscopy. The ring-opening reactions were carried out using the light of a $150-\mathrm{W}$ tungsten source that was passed through a 415 -nm cutoff filter to eliminate higher energy light.

Characterization of the photostationary state containing $\mathbf{4 a}$ and $\mathbf{4 b} . \mathrm{A} \mathrm{CDCl}_{3}$ solution of $4 \mathbf{a}\left(1 \times 10^{-3} \mathrm{M}\right)$ was irradiated with $313-\mathrm{nm}$ light for 1 -minute periods and ${ }^{1} \mathrm{H} \mathrm{NMR}$ 
spectra were obtained after each irradiation. The photostationary state (containing $31 \%$ of the ring-closed isomer $\mathbf{4 b}$ ) was obtained after a total of 4 minutes of irradiation.

4b: ${ }^{1} \mathrm{H}$ NMR $\left(\mathrm{CDCl}_{3}\right) \delta 7.72(\mathrm{~s}, 1 \mathrm{H}, \mathrm{CH}), 7.50(\mathrm{~s}, 1 \mathrm{H}, \mathrm{CH}), 3.23(\mathrm{~m}, 1 \mathrm{H}, \mathrm{CHC}=\mathrm{O}), 3.22$ $(\mathrm{m}, 1 \mathrm{H}, \mathrm{CHC}=\mathrm{O}), 3.12(\mathrm{~m}, 1 \mathrm{H}, \mathrm{CH}), 3.11(\mathrm{~m}, 1 \mathrm{H}, \mathrm{CH}), 2.08\left(\mathrm{~s}, 6 \mathrm{H}, \mathrm{CH}_{3}\right), 1.89(\mathrm{~s}, 3 \mathrm{H}$, $\left.\mathrm{CH}_{3}\right), 1.84\left(\mathrm{~s}, 3 \mathrm{H}, \mathrm{CH}_{3}\right), 1.54\left(\mathrm{~m}, 4 \mathrm{H}, \mathrm{CH}_{2}\right)$.
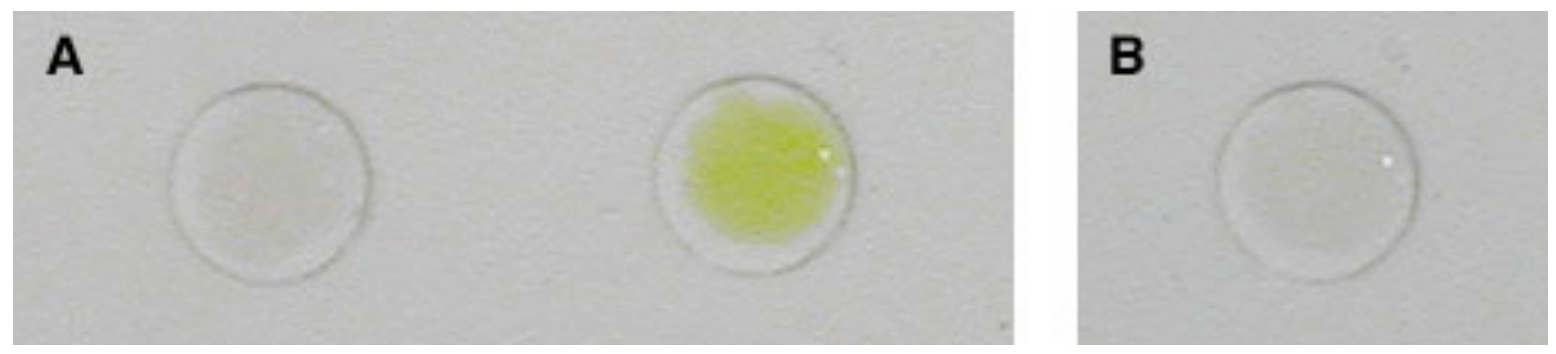

Device Pictures. Cyclohexadiene 4a $(1 \mathrm{mg})$ was added to a saturated solution of maleic anhydride in DMSO $(0.5 \mathrm{~mL})$ and a small amount of DMSO was added $(\sim 0.5 \mathrm{~mL})$ to dissolve the remaining solid. A solution containing only the cyclohexadiene was also prepared ( $1 \mathrm{mg}$ in $1 \mathrm{~mL})$. One drop of each solution was deposited on a microscope slide and placed on a heating stage at $35{ }^{\circ} \mathrm{C}$ for 30 minutes. After this heating period, the samples were simultaneously irradiated for 30 seconds with 313-nm light. The sample containing maleic anhydride and the cyclohexadiene turned yellow. The other did not. The same behaviour was observed when the solution of maleic anhydride and cyclohexadiene and the control solution were kept at room temperature for 14 hours. 